\title{
Seeking Happiness through Materialism, Gratitude and Life Satisfaction: Evidence from Pakistani Employees, with the Mediatory Role of Feeling Experiences
}

\author{
Misbah (Corresponding author) \\ Research Scholar \\ Karachi University Business School (KUBS), University of Karachi \\ KU Circular Road, University of Karachi, Karachi, Pakistan \\ E-mail: mmisbah403@gmail.com
}

Dr. Danish Ahmed Siddiqui

Associate Professor

Karachi University Business School, University of Karachi

KU Circular Road, University of Karachi (KUBS), Karachi, Pakistan

E-mail: daanish79@hotmail.com

Received: November 5, 2019 Accepted: November 23, 2019 Published: November 25, 2019

doi:10.5296/ijmis.v4i1.15765 URL: http://dx.doi.org/10.5296/ijmis.v4i1.15765

\begin{abstract}
This research paper proposed a theoretical framework that focused on the link between materialism and dissatisfaction with life. Through modifying J. A. Roberts (2015) model, we proposed that Seeking Happiness through Materialism is associated with positive or negative feeling experiences, and these experiences produce an effect on one's life satisfaction. Furthermore, we also explored bi-directional impact of gratitude and materialism in two models. In first model, the effect of materialism and life satisfaction was explored with the mediating role of gratitude and feeling experiences, whereas, in second model, the impact of gratitude on life satisfaction was analyzed with the mediation of materialism and experiences. The link was empirically established by collecting the data on 205 employees working in different sectors and professions in Pakistan. Data was collected by means of close ended questionnaire and was analyzed using Confirmatory Factor Analysis and Structure Equation
\end{abstract}




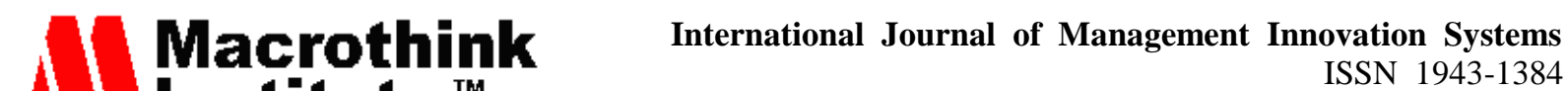 2019, Vol. 4, No. 1}

Modeling. The results showed a significant effect of materialism in employee's life satisfaction and gratitude plays a mediating role. The negative relationship between materialism and life satisfaction among employees indicated as materialism increased satisfaction with life decrease. This was experience directly and through the mediation of feeling experiences. Moreover, Materialism negatively affected gratitude. In the second model, Employees having either high gratitude shows less materialism and positive feeling effect, whereas, employees having low gratitude shows high negative feeling effect because they are seeking happiness through material things. Additionally, those employees who are able to appreciate what they have, are happier and enjoying their life. Thus, feelings, gratitude, and materialism are crucial factors influencing employee's life satisfaction either positively or negatively.

Keywords: Materialism, Life satisfaction, Positive feeling effect, Negative feeling effect, Gratitude, Success, Centrality, Happiness, Pakistan, SEM, CFA 


\section{Introduction}

\subsection{Background to the Study}

"The secret of happiness, you see, is not found in seeking more, but in developing the capacity to enjoy less" - Socrates, lived in $450 \mathrm{BC}$.

The Oxford English Dictionary defines materialism and gratitude as: "devotion to material needs and desires, to the neglect of spiritual matters; a way of life, opinion, or tendency based entirely upon material interests" and "the feeling of being grateful and wanting to express your thanks" respectively. Materialism viewed conflicting with religious fulfillment by every major religion as noted by (Belk, 1983). Additionally, numerous empirical research showed adverse effects of materialism on individuals and society (Kasser, 2002), materialistic beliefs are found to be positively linked with happiness (Belk, 1985). With regard to society, materialism negatively affects the environment, decreases involvement in communities, leads to less charitable donations, and their time together as a family decreases (Droge \& Mackoy, 1995). (Sirgy, 1998) theorized that materialist experience greater dissatisfaction than non-materialist because materialists set standard-of-living goals that are abnormally high and unrealistic. Further he suggests that this dissatisfaction with standard-of-living, spills over to cause dissatisfaction with life in general. The focus on the self- had been implied by materialism and the importance of material resources to the self (Richins \& Dawson, 1992).

Furthermore, above researches showed that materialism has positive affect with negative relationship, Gratitude might be important moderators in the association between life satisfaction and materialism which has to be tested by the positive related constructs. On the other hand, in contrast to materialism, when someone perceives that another person has intentionally given him or her a valued benefit gratitude has been experienced showed that gratitude is a positive emotion (McCulough, Kilpatrick, Emmons, \& Larson, 2001) (Tsang, 2007). Gratitude linked empirically with the various indices of well-being both as a state and a trait, for example (Emmons \& McCullough, 2003) found that a number of gratitude journals which is completed by different individuals in many weeks showed more positive life appraisals and better expectations for the coming week, when compared to individuals who instead wrote about daily hassles. For instance, (McCulough, Emmons, \& Tsang, The grateful disposition: A conceptual and empirical topography, 2002) found that grateful disposition is positively related to self- and other-related well-being variables such as life satisfaction, happiness, hope, optimism, vitality and positive affect and negative related to depression and anxiety. Grateful disposition to be positively related to positive affect, life satisfaction, internal and divine locus of control, happiness and true religiousness and negatively related to aggression, extrinsic religiousness and narcissism (Watkins, Woodward, Stone, \& Kolts, 2003). Gratitude and materialism in some ways thought as conceptual opposites. Whereas a focus of gratitude is on others and the benefits those others have provided in one's life (Lambert, Fincham, Stillman, \& Dean, 2009). Through gratitude individuals are able to move from the focus on the self to the focus on others, thus restringing negative affect that might come with self-focus and replacing it with the positive affect that comes from realizing that one has received benefits from others (Watkins, 2014). These all 
articles clearly demonstrate the mediating role of gratitude and positive affect on the relationship between materialism, negative affect and life satisfaction. If materialism has the ability to decrease life satisfaction by increasing negative affect, then gratitude has also a power of decreasing negativity from one's life by increasing the positive affect.

(Deckop, Jurkiewicz, \& Giacalone, 2010) found that including intrinsic and extrinsic reward satisfaction, job satisfaction, and career satisfaction, materialistic values are negatively associated with a range of indicators of work-related personal well-being. Suggested by previous analysis, the relationship between materialism and work-related personal well-being is driven by the happiness and centrality dimensions of materialism, and not by the success dimension. Organizations focus on effects of materialism for a number of reasons. First, organizations can and do play a significant role in addressing personal needs through workplace practices that contribute to the quality of work life (Gagne \& Deci, 2005). Second, it distributes as pay because of the connection to economic rewards, the organization is an arena where materialistic concerns are firmly entrenched and salient. The ability for a work organization to pay its employees, for example, is a main criterion in its survival; as such, materialistic concerns are always primary (Deckop, Jurkiewicz, \& Giacalone, 2010). Because of the primacy of money in organizational life is another reason, the implications of materialism are prevalent, for it is apparently impactful even to those without materialistic values (Inglehart, 1990). One of the key moral underpinnings of present-time management thought is materialism, and its resultant emphasis on productivity and efficiency (Dyck \& Schroeder, 2005). As a core value, materialist organizational cultures communicate the primacy of materialism, that management principles are likely to be based on this value, and that employees are likely to be rewarded to the extent they view work life as instrumental to the attainment of material possessions (Kasser, Vansteenkiste, \& Deckop, 2006). (Grant \& Gino, 2001) found that expecting others to feel grateful motivates individuals to invest additional time and energy in efforts to benefit them.

As more researchers have begun to explore factors that affect life satisfaction of employees, there has been increasing attention to the effect of materialism in employee's life. Seeking happiness through material purchase in increasingly relate to lower level of life satisfaction and associated with several negative affect of well-being. In a long term materialist employees lose their efficiency and interest in their work if they will not find what they want and ultimately it will affect the organizational overall goals but if they are able to appreciate what they have and praise those things it will increase the positive affect in their life and decrease negativity from their life. So that they life will be satisfied and they will be able to spend their life with happiness.

\subsection{Problem Statement}

It is observed that employees are not satisfied with their life and with the things they have because they are seeking for more material things in search of happiness. But if they learn to stay happy with the things, they have they will spend their life happily. Materialism reduces the fun of their life and decrease the satisfaction with their job they won't be able to enjoy their work. In current study we will discuss about these issues. Historical-geographical 


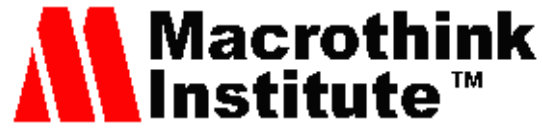

International Journal of Management Innovation Systems

ISSN 1943-1384

2019, Vol. 4, No. 1

materialism starts from the premise that things (as objects or phenomena) exists, but that these objects or phenomena are the embodiment of (they interiorize) relationships; things become the outcome of processes that have themselves ontological priority (Swyngedoun, 2000). Materialist theory is far more upfront about political change. It will only be achieved through struggle, and that struggles will be by oppressed groups themselves against the forces that oppress them. In order to do this, it is necessary for oppressed groups to organize collectively to confront this oppression. That inevitably means confrontation and conflict with powerful groups, interests and structures for there are few examples in human history of people willingly giving up power to others (Oliver, 1999). If we link materialism to capitalism Marx's explain this relationship as "the Marxist theory of capitalism does not work on idealist sociology but on the materialist conception of history. As we have seen, the materialist conception of history enfolds theoretically the "general laws" (Engels) of social development, at the same time including the "laws of movement" of different historical structures as a whole, the reproduction of the whole of social life, from its materialist basis to its ideological sublimations. The reproduction only of these materialist foundations was analyzed by economic theory.

This research explains how materialism effects on employees (i.e. positively or negatively) and its impact on gratitude and life satisfaction through two models. This research will contribute in the society to find how individuals and employees think about material things and their priorities about their life whether they are losing happiness and fun and satisfaction with their life in search of more and more or they enjoy their life in what they have. Our models explain from both aspects by taking gratitude as an independent variable and by taking materialism (i.e. success, centrality and happiness) as independent variables in second model to find the empirical results on these issues. Further we will discuss either employees and individuals find happiness through material things or gratitude.

\subsection{Gap Analysis}

One of the foremost issues involving materialism that needs to be addressed is whether materialism is a positive or a negative trait. Arguments claiming that it is a negative trait, (Christopher et al., 2004) found that individual differences in materialism were related to increased negative affect and decreases positive affect.

There are conflicting ideas about materialism in social messages. A number of researches have documented a negative relationship between materialism and satisfaction with life and positive affect. A growing body of research demonstrates that materialistic individuals score lower on indicators such as happiness, well-being, mental health, life satisfaction, physical health and positive affect. Previous studies also shown that materialism predicts decrease life satisfaction. Higher scores of materialism increased life dissatisfaction not only with one's standard of living, but also reduced the amount of entertainment in life and relationship with others along with dissatisfaction with life as a whole. Materialists on average are less happy according to numerous researches. (Roberts, Tsang, \& Manolis, 2015) relate materialism with negative affect and they predicted that negative affect would the effect of materialism on life satisfaction and proposed a model to explain materialism and life dissatisfaction. Additionally, 
they predicted that gratitude would moderate the relationship between materialism and both negative affect and satisfaction with life such that the positive affect will be lessened as a function of gratitude and the negative effect of materialism on satisfaction with life will also be diminished as a function of gratitude and their results are consistent with their predictions. The findings of previous research suggested that the helpful effects associated with both gratitude and positive affect were needed to prevent materialism from negatively influencing one's satisfaction with life (i.e. higher levels of either moderating variable by itself were not enough). The interaction of the two moderating variables did not affect materialism. (Ashikali \& Dittmar, 2011) found priming materialism heightens the centrality of appearance to women's self-concept and priming materialism influences the activation of body related self-discrepancies (BRSDs), particularly for highly materialistic women. Disclosure to materialistic media has a clear influence on women's body image, with trait materialism a further vulnerability factor for negative exposure effects in response to idealized, thin media models. This research is done on women's responses of United Kingdom. (CHAPLIN \& JOHN, 2007) they examined age differences in materialism with children and adolescents 8-18 years old. In study 1, they found materialism increases from middle childhood to early adolescence and declines from early to late adolescence. Further, they found that age differences are mediated by changes in self-esteem occurring from middle childhood through adolescence. In study 2, they prime self-esteem to obtain further evidence of a causal link between self-esteem and materialism. As expected, they found that inducing high self-esteem decreases expressions of materialism. Inducing high self-esteem reduces materialism among adolescents so adequately that age differences in materialism vanish. (Lyubomirsky, Sheldon, \& Schkade, 2007) argue that there are three major factors that relate to a person's happiness; i.e., (a) a genetically determined set-point; (b) circumstantial factors (e.g., income or education); and (c) activities and practices that relate to happiness. Deliberate interventions address the latter point.

Numerous researches show that there is a negative affect between materialism and different personality traits but in this research, we discuss these variables in different aspect from the employees' point of view. In this research we also analyze the mediatory (i.e. positive affect and negative affect) to find the relationship between materialism and both gratitude and life satisfaction from the evidence of Pakistani employees. Although the effects of these variables have been investigated in separate research literatures, no previous research has examined whether effects of materialism and gratitude linked to employee's responses. There are no empirical data found on experimentally addresses whether effect of materialism and gratitude relate with employee's life satisfaction in Pakistan and other developing countries. Moreover, most studies did not fit well for developing countries.

\subsection{Research Objectives}

The main aim of this research is to cope the issues of employees regarding satisfaction with life and the effects of materialism and gratitude with the satisfaction of their life and to analyze the mediating role of feeling experiences from the responses of Pakistani employees from different Public and Government sector organizations. 


\section{MInstitute Macrothink $_{\text {Int }}$}

International Journal of Management Innovation Systems

ISSN 1943-1384

2019, Vol. 4, No. 1

From the literature review it was identified that there is a negative affect between materialism and one's life satisfaction as materialism increases it will decrease the satisfaction with life but when someone is able to appreciate what they have it will increase the satisfaction of life.

The current research aimed to measuring the relationship between materialism, gratitude and life satisfaction among employees testing the mediatory role of positive and negative affect. It was strongly indicated a link between materialism and dissatisfaction with life among employees. This research proposes that one way that materialism adversely affects life satisfaction is through its relationship with negative affect. We suggested that in employees, the relationship between materialism and decreased life satisfaction may be more complicated than it appears. However, employees who are able to appreciate what they already have even while they are engaging in seeking more might be able to maintain high levels of life satisfaction. We investigate the mediating effect of gratitude and feeling experiences on detrimental relationship between materialism and life satisfaction among employees. A sense of gratitude decreases materialism by increasing one's life satisfaction.

- To determine the effect of materialism on employee's life satisfaction.

- To identify the mediating role of gratitude in employee's life satisfaction.

- To identify the Gratitude-life satisfaction relationship.

- To examine whether gratitude lessened the effect of materialism in employee's life and vice versa.

- To determine the mediatory role of positive negative feeling effects life satisfaction among employees.

\subsection{Significance of the Study}

Materialism is defining aspects of many social cultures. Unfortunately, a large number of research documented materialism a negative relationship between materialism and other traits of non-work personal well-being. This study extends the materialism into the organizational perspective. It is beneficial for companies to identify the satisfaction level of employee's life. For employees, it is beneficial in terms that how they will eliminate the negative affect of materialism from their life. If they will be able to enjoy less rather than seeking more in search their life will be satisfied. (Dittmar, et al., 2014) associate materialism with lower self-esteem. Now a day many researches shows that people are not happy with their lives and increased depression, anxiety and are losing interest in their work so we will tackle one of the problems of these issues facing by employees and individuals. Hence this would be helpful for both employees and organizations.

\section{Literature Reviews}

\subsection{Materialism and Negative Affect}

Materialism is associated with lower self-esteem, lower well-being and health and more risk behaviors (Dittmar et al., 2014) they collected 259 samples from individuals. Even though this body of evidence, however, we still know little about why (i.e., explaining mechanisms) 
and when (i.e., boundary conditions) materialism has such a negative impact. Consistent negative association between a broad array of types of personal well-being and people's belief in and prioritization of materialistic pursuits in life was clearly demonstrated by this meta-analysis (Kasser, 2002) concludes that a value system dominated by materialistic values undermines one's sense of self, the quality of his or her relationships, and willingness to get involved in community events. (Rakrachakarn, Moschis, Ong, \& Shannon, 2015) examines the role of religiosity and religion in the relationship between materialism and life satisfaction. Religion may be a key factor in understanding differences in findings of previous studies regarding the inverse relationship found in the vast majority of previous studies. The findings also suggested that the influence of religiosity on materialism and life satisfaction is stronger among Malays than among Chinese and Indians, and life satisfaction partially mediates the relationship between religiosity and materialism.

Worse mental health in individuals with low and medium mindfulness levels were predicted by greater materialism. The effect of materialism on mental health was no significant in individuals with high mindfulness levels. Their findings have implications for interventions against the negative effect of materialism (Wang, Liu, Tan, \& Zheng, 2017). Materialism is also associated with several negative indicators of well-being, such as loneliness as examined by (Pieters, 2013). (Kashdan \& Breen, 2007) tested the hypothesis that experiential avoidance mediates associations between materialistic values and diminished emotional well-being, meaning in life, self-determination, and gratitude. People with stronger materialistic values reported more negative emotions and less relatedness, autonomy, competence, gratitude, and meaning in life had indicated by results. As expected, experiential avoidance fully mediated affiliations between materialistic values and each dimension of well-being.

Hypothesis: Negative affect would mediate the effect of materialism (i.e. Success, Centrality and Happiness) on life satisfaction. (For both model).

Hypothesis: Materialism (i.e. success, centrality and happiness) has significant negative relationship with positive affect.

\subsection{Materialism and Life Satisfaction:}

Numerous researches show that happiness seeking through material things is negatively related to life satisfaction. For instance, (Roberts, Tsang, \& Manolis, 2015) proposed a model that explains the negative relationship between materialism and life satisfaction. Result shows that materialism exhibited a significant direct and negative affect on satisfaction with life. And materialism had a positive relationship with negative affect. Negative affect had a negative relationship with satisfaction with life gratitude and positive affect together would also reduce negative effects on materialism and satisfaction with life. (Promislo, Deckop, Giacalone, \& Jurkiewicz, 2011) examined the relationship between materialism and two components of work-family conflict: work interference with family (WIF) and family interference with work (FIW). Results supported main hypotheses that materialism is associated with both forms of work-family conflict.

Hypothesis: Materialism (i.e. Success, Centrality and happiness) has a significant negative 


\section{Macrothink \\ International Journal of Management Innovation Systems \\ ISSN 1943-1384 \\ 2019, Vol. 4, No. 1}

impact on satisfaction with life. (For both Model)

\subsection{Gratitude and Materialism}

As a cause of unhappiness materialistic strivings have been implicated. Gratitude, on contrary- both in its demonstrations as a chronic affective trait and as a more temporary emotional experience - may be a cause of happiness. (Polak \& McCullough, 2006) review the empirical research on the relationships among materialism, gratitude, and well-being. They presented new correlational data on the gratitude-materialism relationship and propose that gratitude may have the potential to reduce materialistic strivings and consequently diminish the negative effects of materialistic strivings on psychological well-being.

For instant, (Froh, Emmons, Card, Bono, \& Wilson, 2011) found that gratitude, controlling for materialism, uniquely predicts all outcomes considered: higher grade point average, life satisfaction, social integration, and absorption, as well as lower envy and depression. In contrast, materialism, controlling for gratitude, uniquely predicts three of the six outcomes: lower grade point average, as well as higher envy and life satisfaction. Furthermore, when examining the relative strengths of gratitude and materialism as predictors, they found that gratitude is generally a stronger predictor of these six outcomes than is materialism.

Hypothesis: Gratitude and materialism (i.e. success, centrality and happiness) has an inverse relationship. (For model 2).

\subsection{Gratitude, Feelings and Life Satisfaction:}

(Cooyoumdjian \& Petrocchi, 2016) found that gratitude significantly predicts less depression and anxiety symptoms in general population. (Disabato, Kashdan, Short, \& Jarden, 2017) Investigated if personality strengths could predict positive life events that aid in the alleviation of depression. They tested a longitudinal mediation model where gratitude and meaning in life lead to increased positive life events and, in turn, decreased depression. Higher level of gratitude and meaning in life each predicted decreases in depression over 3and 6-months' time.

Higher levels of gratitude significantly predicted increases in social support, adaptive coping abilities, and beneficial psychological outcomes (e.g., life satisfaction), as well as decreases in avoidant coping style and detrimental physical outcomes (e.g., negative emotions) (Lin \& Che, 2015). Further, they found that gratitude could induce other positive emotions which partially mediated the effects of gratitude on emotional well-being.

Gratitude resulted in higher satisfaction with life and lower materialism, such that stronger feelings of gratitude associated with lower materialism (Lambert N. M., Fincham, Stillman, \& Dean, 2009) controlling for positive and negative affect reduces the likelihood that positive mood (potentially generated by the high gratitude condition) or negative mood (potentially generated by the envy/low gratitude condition) was responsible for between-group differences. 


\section{Macrothink}

International Journal of Management Innovation Systems

ISSN 1943-1384

2019, Vol. 4, No. 1

(Proyer, Ruch, \& Buschor, 2013) found that hope, zest, love, and gratitude were the best predictors of life satisfaction out of 24 positive psychology traits. The relationship between grateful personality and well-being tends to hold true across both self- and other reports. There was an increase in life satisfaction in a group that underwent interventions on curiosity, gratitude, hope, humor, and zest (medium effect sizes). It is expected that there are general patterns for strength-based interventions (e.g., enabling positive emotions; fostering engagement; etc.) but that there are also strengths-specific processes and mechanisms (e.g., zest-interventions may induce higher physical activation and may facilitate physical well-being).

(Muceldili, Erdil, Akgun, \& Keskin, 2015) proposed that contextual performance, team learning, and high-quality connection is enhanced by cultivating collective gratitude.(McCulough, Kilpatrick, Emmons, \& Larson, 2001) examined the associations of subjective well-being and the disposition to experience gratitude in a slightly different way: They correlated measures of subjective well-being (e.g., trait positive affect, negative affect, optimism, etc.) with the mean level of gratitude that participants reported in their daily mood reports over the course of several weeks. In both studies (grateful mood was measured for 21 consecutive days in Study 1 and 14 consecutive days in Study 2), satisfaction with life, positive affect, and optimism were positively linked to the mean levels of grateful mood that people reported in their daily diaries. Depressive symptoms were negatively related with the mean level of grateful mood in participants' daily mood reports. In other words, people with higher satisfaction with life, positive affect, and optimism, and lower depressive symptoms, tended to experience higher levels of gratitude in their daily mood on a day-to-day basis. Taken together, these four studies provide strong support for the proposition that grateful people tend to report being happier, more optimistic, more satisfied with their lives, and less anxious and depressed than do their fewer grateful counterparts.

Hypothesis: Positive Affect would mediate the effect of gratitude on life satisfaction. (For both Model).

Hypothesis: Gratitude is significantly associated with positive affect. (For both Model).

Hypothesis: Gratitude has a negative relationship with negative affect. (For both Model).

Hypothesis: Gratitude has a significant positive relationship with life satisfaction. (For both Model).

Hypothesis: Gratitude and materialism (i.e. success, centrality and happiness) has an inverse relationship. (For model 2).

\section{Theoretical Framework}

Being obsessed with the hunt of money, wealth, and material possessions arguably fails as a strategy to increase pleasure and meaning in life. However, little is known about the mechanisms that explain the opposite relation between materialism and well-being. (Richins \& Dawson, 1992) define materialism as a "value that emphasis importance of possessions and material goods in person's life toward achieving life goals or desired states". They 


\section{Mll Macrothink}

International Journal of Management Innovation Systems

ISSN 1943-1384

2019, Vol. 4, No. 1

developed material values scale (MVS) to measure materialism in consumers. Since then, the scale has been used in various studies. The development of a short form of the MVS also described by the article. A short form of this measure would be useful for a number of reasons. First, it would take up less space on a survey instrument, allowing researchers to include additional measures of other constructs on the same questionnaire. Second, a shorter measure would reduce demand effects or hypothesis guessing when the measure is used in experiments and surveys. The MVS tends to draw attention to itself because of the relatively large number of items dealing with similar (materialistic) issues. It is difficult to disguise so many items by embedding them within other items on different topics. Third, in many research efforts materialism is not the main construct of interest, yet the researcher may have reason to believe that materialism might be a useful variable to explore in relation to the primary construct. If a long form of the materialism measure is the only one available, the researcher may be forced to forego measurement of materialism to keep the survey at a reasonable length or may develop ad-hoc measures of materialism of untold validity. They defined materialism with three components: (1) centrality, or making acquisition of material possessions a central focus of one's life; (2) happiness, or making the pursuits of material possessions of one's main source of life satisfaction, and (3) success, or viewing possessions as a marker for success. We restrict our discussion of materialism to the happiness facet, defining materialism as the degree to which one believes that material possessions are a large determinant of one's happiness in life, given its importance for life satisfaction. The background of this research explained the MVS treats materialism as a value that influences the way that people interpret their environment and structure their lives. The MVS possesses an adequate degree of internal consistency indicated by the analysis of published studies. However, questions remain concerning the dimensional purity of the MVS and possible influences of SDR on responses. (Tsang, Carpenter, Roberts, Frisch, \& Carlisle, 2014) relate materialism with lower levels of life satisfaction. They suggest that one reason for this negative relationship is that high materialist find it difficult to be grateful, and lower levels of gratitude be related to unmet psychological needs. Gratitude and need satisfaction played important mediating roles for the adverse relationship between materialism and life satisfaction, mediating $50 \%$ of the link between materialism and life satisfaction. Generally, materialism is considered as a negative value, trait or behavior, being associated with greed, shallowness and lack of spiritual values. Experiencing gratitude, thankfulness, and appreciation tends to foster positive feelings, which in turn, play a part in one's overall sense of well-being. Therefore, gratitude appears to be one component, among many components, that contributes to an individual's well-being. (Sansone \& Sansone, 2010). (Emmons \& McCulough, 2003) examined gratitude and well-being under three experimental conditions. Participants were divided into three groups (i.e., one group was asked to journal about negative events or hassles, a second group about the things for which they were grateful, and a third group about neutral life events) and were required to journal either daily or weekly. Across the various study conditions, the gratitude subsample consistently evidenced higher well-being in contrast with the other two study groups. (Erdogan, Bauer, Truxillo, \& Mansfield, 2011) defined life satisfaction as key indicator of subjective well-being. They believed that life satisfaction is an important outcome to consider alongside other key 


\section{Mll Macrothink}

International Journal of Management Innovation Systems

ISSN 1943-1384

2019, Vol. 4, No. 1

management variables such as job attitudes and behaviors. Happiness of the individual has been a key concern for individuals and societies across the ages. Over 2,300 years ago, in his Nicomachean Ethics, Aristotle discussed happiness as the ultimate goal in human existence, as it is important for its own sake, rather than being a means to an end. This idea is still valid, with survey results from 41 nations showing that happiness is a very important goal for almost everyone surveyed (Diener, Sapyta, \& Suh, 1998). (McCullough, Emmons, \& Tsang, 2002) argue that gratitude should be related to satisfaction with life as gratitude has a positive valiance, and the greater experience of positive emotions is related to satisfaction with life.

\subsection{Hypothesis}

In the light of literature reviews following hypothesis has been developed:

\section{(For Model 1)}

H1: Success has a significant negative impact on gratitude.

$\mathrm{H} 2$ : Success has a significant negative impact on life satisfaction.

H3: Success is associated with negative affect.

H4: Success has significantly negative relationship with positive affect.

H5: Centrality has a significant negative impact on gratitude.

H6: Centrality has a significant negative impact on life satisfaction.

H7: Centrality is associated with negative affect.

H8: Centrality has significant negative relationship with positive affect.

H9: Seeking happiness with material possession has a significant negative impact on gratitude.

H10: Seeking happiness with material possession has a significant negative impact on life satisfaction.

H11: Seeking happiness with material possession is associated with negative affect.

H12: Seeking happiness with material possession has significant negative relationship with positive affect.

H13: Negative affect would mediate the effect of materialism (i.e. Success, Centrality and Happiness) on life satisfaction.

H14: Positive Affect would mediate the effect of gratitude on life satisfaction.

H15: Gratitude is significantly associated with positive affect.

H16: Gratitude has a negative relationship with negative affect.

H17: Gratitude has a significant positive relationship with life satisfaction. 


\section{Macrothink}

(For Model 2.):

H1: Gratitude has inverse relationship with success.

H2: Gratitude has inverse relationship with Centrality.

H3: Gratitude has inverse relationship with happiness.

H4: Gratitude is associated with positive affect.

H5: Gratitude has a negative relationship with negative affect.

H6: Gratitude has a significant positive impact on life satisfaction.

H7: Success has a significant negative impact on life satisfaction.

H8: Success is associated with negative affect.

H9: Success has significant negative relationship with positive affect.

H10: Centrality has a significant negative impact on life satisfaction.

H11: Centrality is associated with negative affect.

H12: Centrality has significant negative relationship with positive affect.

H13: Seeking happiness with material possession has a significant negative impact on life satisfaction.

H14: Seeking happiness with material possession is associated with negative affect.

H15: Seeking happiness with material possession has significant negative relationship with positive affect.

H16: Negative affect would mediate the effect of materialism (i.e. Success, Centrality and Happiness) on life satisfaction.

H17: Positive Affect would mediate the effect of gratitude on life satisfaction.

\subsection{Conceptual Model}



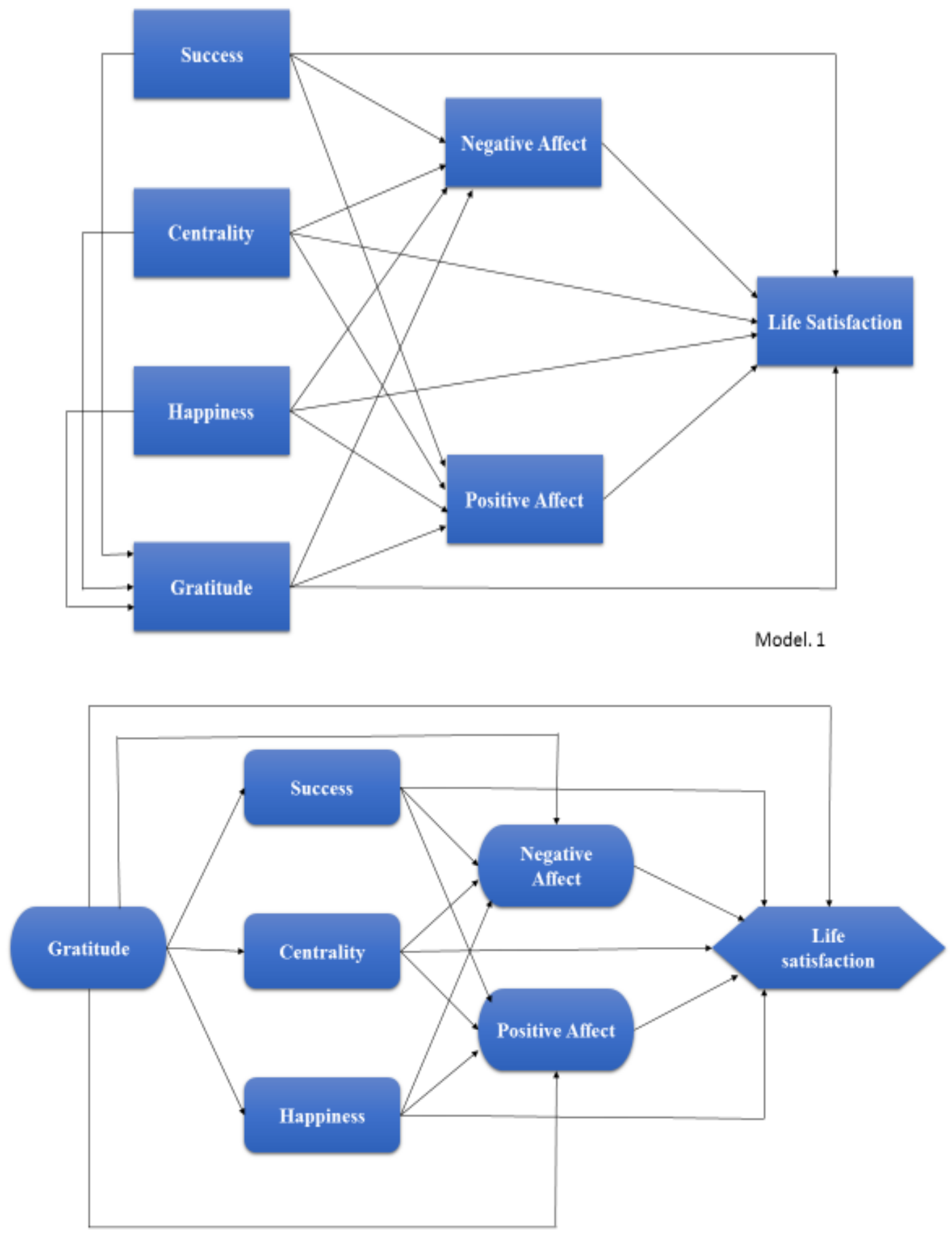

Model. 2

Figure 1.

Description for the above Models.

According to hypothesis we developed two models in first model, we take success, centrality and seeking happiness through material possession as independent variables and all others are 


\section{Macrothink}

International Journal of Management Innovation Systems

ISSN 1943-1384

dependent. Whereas, in second model, we take gratitude as independent variable and all the others are dependent variables.

\section{Research Methodology}

Participants completed the 8-10 minutes' survey. Data were collected via self-report questionnaires using SmartPLS3 survey software. Potential respondents were sent an online Google form link via e-mail and social media or manually through hard copy of survey questionnaire. Out of 250 survey questionnaires sent to employees, 209 usable questionnaires were completed for an $83.6 \%$ response rate.

\subsection{Partiticipants and Procedures}

Table 1. Descriptive statistics (Demographic profile):

\begin{tabular}{|c|c|c|}
\hline Variables & Options & Percentage \\
\hline \multirow[t]{2}{*}{ Gender } & Male & 63.2 \\
\hline & Female & 36.8 \\
\hline \multirow[t]{4}{*}{ Age } & 20-25 years & 36 \\
\hline & 25-35 years & 53.11 \\
\hline & $35-45$ years & 6.2 \\
\hline & Above 45 years & 4.8 \\
\hline \multirow[t]{2}{*}{ Marital Status } & Single & 72.68 \\
\hline & Married & 27.32 \\
\hline \multirow[t]{6}{*}{ Income Level } & Below Rs.20,000 & 11.7 \\
\hline & Rs. $20,000-40,000$ & 48.78 \\
\hline & Rs.40,000-60,000 & 15.6 \\
\hline & Rs.60,000-80,000 & 7.3 \\
\hline & Rs. $80,000-100,000$ & 6.8 \\
\hline & Above Rs.100,000 & 9.8 \\
\hline \multirow[t]{6}{*}{ Level of Education } & Matriculation & 00 \\
\hline & Intermediate & 4.4 \\
\hline & Graduate & 46.8 \\
\hline & Masters & 41.46 \\
\hline & M.Phil. & 4.9 \\
\hline & $\mathrm{PhD}$ & 2.4 \\
\hline \multirow[t]{7}{*}{ Profession } & Doctor & 1.95 \\
\hline & Engineer & 20.49 \\
\hline & Self-Employed & 6.8 \\
\hline & Entrepreneur & 5.36 \\
\hline & Private Employee & 51.7 \\
\hline & Banker & 3.9 \\
\hline & Teacher & 9.75 \\
\hline
\end{tabular}




\section{MInstitute ${ }^{\text {Macrothink }}$}

International Journal of Management Innovation Systems

ISSN 1943-1384

2019, Vol. 4, No. 1

Description for the above table.

Participants were 209 (77 Female) employees from different sectors and different professions $1.95 \%$ of the sample was Doctor, $20.49 \%$ Engineers, $6.8 \%$ Self-employed, $5.36 \%$ Entrepreneur, 51.7\% Private Employees, 3.9\% Bankers, 9.75\% Teachers. Age of participants $36 \%$ lies between $20-25$, majority $53 \%$ lies between $25-35,6.2 \%$ were $35-45$ years old and $4.8 \%$ were above 45 years. The majority belongs to Karachi $89.27 \%, 10.73 \%$ belongs to other areas of Pakistan. Income level of the participants were 11.7\% participants earned below Rs. 20,000 monthlies, $48.78 \%$ earned 20k-40k, $15.6 \%$ earned 40k-60k, $7.3 \%$ earned 60k-80k, 6.8\% earned 80k-100k and 9.7\% earned above 100k monthly in PKR. $72.68 \%$ participants were single and $27.32 \%$ were married. $4.4 \%$ participants were intermediate, $46.8 \%$ graduate, $41.46 \%$ masters and $4.9 \%$ M.Phil., $2.4 \%$ have $\mathrm{PhD}$ degree.

\subsection{Measures}

\subsubsection{Materialism}

I measured materialism using 15-item version of (Richins \& Dawson, 1992) material values scale. The scale measures three dimensions of materialism with five items each: happiness, centrality, and success. In the present research, only the five-item happiness dimension was utilized (sample item, 'My life would be better if I owned certain things I don't have', $1=$ Strongly disagree, $5=$ Strongly agree). A higher score on the happiness dimension of materialism suggests that the respondent views material possessions as a route to happiness. This subscale had composite reliability for our sample success, centrality and happiness was $\alpha=0.74,0.65 \& 0.77$ respectively.

\subsubsection{Gratitude}

Dispositional gratitude was measured using the Gratitude Questionnaire - 6 (McCullough, Emmons, \& Tsang, 2002). This six-item measure has good psychometric properties (sample item, 'I have so much in life to be thankful for', $1=$ Strongly disagree, $5=$ Strongly agree). Reliability for this sample was good, $\alpha=0.70$.

\subsubsection{Positive and Negative Affect}

Positive and negative affect was measured using the scale of positive and negative experience (SPANE) developed by (Diener et al., 2009). The SPANE consists of 12 items (six positive and six negative feelings). Respondents were asked to report how often in the past four weeks they have experienced the 12 feelings of the SPANE scale. Response categories ranged from very rarely or never (1), rarely (2), sometimes (3), often (4), to very often or always (5). Reliability for the negative affect subscale was 0.72 and 0.82 for the positive affect subscale.

\subsubsection{Life Satisfaction}

We measured life satisfaction with the five-item satisfaction with life scale (Diener, Emmons, Larsen, \& Griffin, 1985). Items are rated on a seven-point Likert-type scale (1=strongly disagree, 5=strongly agree; sample item, 'I am satisfied with my life'). Reliability for this sample was good, $\alpha=0.80$. 


\section{Results of the Study}

\subsection{Descriptive Statistics}

Table 2. (Items, mean, standard deviation and standard error)

\begin{tabular}{|c|c|c|c|c|}
\hline Code & Items & Mean & $\begin{array}{l}\text { Standard } \\
\text { Deviation }\end{array}$ & $\begin{array}{l}\text { Standard } \\
\text { Error }\end{array}$ \\
\hline & Success: & & & \\
\hline Q1 & I admire people who own expensive homes, cars, and clothes. & 2.775 & 1.242 & 0.085 \\
\hline Q2 & $\begin{array}{l}\text { Some of the most important achievements in life include } \\
\text { acquiring material possessions. }\end{array}$ & 2.914 & 1.183 & 0.081 \\
\hline Q3 & $\begin{array}{l}\text { I don't place much emphasis on the amount of material objects } \\
\text { people own as a sign of success. }\end{array}$ & 2.974 & 1.196 & 0.082 \\
\hline Q4 & The things I own say a lot about how well I'm doing in life. & 2.981 & 1.237 & 0.085 \\
\hline Q5 & $\begin{array}{l}\text { I like to own things that impress people. } \\
\text { Centrality: }\end{array}$ & 2.756 & 1.261 & 0.087 \\
\hline Q6 & I usually buy only the things I need. & 3.220 & 1.480 & 0.102 \\
\hline Q7 & $\begin{array}{l}\text { I try to keep my life simple, as far as possessions are } \\
\text { concerned. }\end{array}$ & 3.311 & 1.321 & 0.091 \\
\hline Q8 & The things I own aren't all that important to me. & 2.780 & 1.182 & 0.081 \\
\hline Q9 & I enjoy spending money on things that aren't practical. & 2.603 & 1.279 & 0.088 \\
\hline Q10 & $\begin{array}{l}\text { Buying things gives me a lot of pleasure. } \\
\text { Happiness: }\end{array}$ & 2.933 & 1.247 & 0.086 \\
\hline Q11 & I have all the things I really need to enjoy life. & 2.976 & 1.296 & 0.089 \\
\hline Q12 & My life would be better if I owned certain things I don't have. & 3.053 & 1.257 & 0.086 \\
\hline Q13 & I'd be happier if I could afford to buy more things. & 3.024 & 1.270 & 0.087 \\
\hline Q14 & $\begin{array}{l}\text { It sometimes bothers me quite a bit that I can't afford to buy all } \\
\text { the things I'd like. }\end{array}$ & 2.957 & 1.171 & 0.081 \\
\hline Q15 & $\begin{array}{l}\text { I wouldn't be happier if I owned nicer things. } \\
\text { Gratitude: }\end{array}$ & 2.728 & 1.219 & 0.084 \\
\hline Q16 & I have so much in life to be thankful for. & 3.703 & 1.483 & 0.102 \\
\hline Q17 & $\begin{array}{l}\text { If I had to list everything that I felt grateful for, it would be a } \\
\text { very long list. }\end{array}$ & 3.715 & 1.425 & 0.098 \\
\hline Q18 & When I look at the world, I don't see much to be grateful for. & 2.622 & 1.365 & 0.094 \\
\hline Q19 & I am grateful to a wide variety of people. & 3.268 & 1.224 & 0.084 \\
\hline Q20 & $\begin{array}{l}\text { As I get older, I find myself more able to appreciate the } \\
\text { people, events, and situations that have been part of my life } \\
\text { history. }\end{array}$ & 3.455 & 1.348 & 0.093 \\
\hline Q21 & $\begin{array}{l}\text { Long amounts of time can go by before I feel grateful to } \\
\text { something or someone. }\end{array}$ & 3.187 & 1.260 & 0.087 \\
\hline
\end{tabular}




\section{MlMacrothink}

International Journal of Management Innovation Systems

ISSN 1943-1384

2019, Vol. 4, No. 1

\begin{tabular}{llrrr}
\hline & Feeling Experiences: & 3.373 & 1.281 & 0.088 \\
Q22 & Positive & 3.239 & 1.007 & 0.069 \\
Q23 & Negative & 3.287 & 1.192 & 0.082 \\
Q24 & Good & 3.344 & 1.070 & 0.074 \\
Q25 & Bad & 3.335 & 1.183 & 0.081 \\
Q26 & Pleasant & 3.411 & 1.104 & 0.076 \\
Q27 & Unpleasant & 3.507 & 1.195 & 0.082 \\
Q28 & Happy & 3.139 & 1.270 & 0.087 \\
Q29 & Sad & 3.445 & 1.185 & 0.082 \\
Q30 & Afraid & 3.426 & 1.255 & 0.084 \\
Q31 & Joyful & 3.081 & 1.244 & 0.086 \\
Q32 & Angry & 3.048 & 1.213 & 0.083 \\
Q33 & Contended & & & \\
& Life Satisfaction: & 3.005 & 1.192 & 0.082 \\
Q34 & In most ways my life is close to my ideal. & 3.244 & 1.147 & 0.079 \\
Q35 & The conditions of my life are excellent. & 3.502 & 1.226 & 0.084 \\
Q36 & I am satisfied with my life. & 3.445 & 1.132 & 0.078 \\
Q37 & So far, I have gotten the important things I want in life. & 2.818 & 1.251 & 0.086 \\
Q38 & If I could live my life over, I would change almost nothing. & & \\
\hline
\end{tabular}

Description for the above table.

Table 2 presented the mean, standard deviation and standard error values for all core indicators of success, centrality, happiness, gratitude, feelings and life satisfaction. Item related to success have mean score in range 2.756-2.2.981 while the same item deviates in range 1.183-1.261. However, overall mean values are below than average which posits response are more likely towards "Strongly Disagree" at five points Likert scale Items related to centrality have mean score in range 2.603-3.220 and deviates in range 1.182-1.480. Items related to happiness have mean score 2.728-3.053 and deviates in range 1.171-1.296. However, responses for both centrality and happiness are dispersed widely and ranged below average to above average. Items related to gratitude have mean score 2.622-3.715 and deviates in range 1.224-1.483 which posits responses are dispersed widely and ranged below average to above average. Items related to feelings experiences have mean score 3.048-3.507 while the same item deviates in range 1.007-1.281. Overall, mean values are above than average which posits response are more likely towards "Strongly Agree" at five points Likert scale. Items related to life satisfaction have mean score 2.818-3.502 and deviates in range 1.132-1.251 which posits responses are dispersed widely and ranged below average to above average.

\subsection{Structural Equation Modeling}

To test the study hypothesis, we have used the structural equation model (SEM) whereas the testing has been gone through Smart PLS software. Moreover, to evaluate the indirect and direct effects of all the constructs the testing was done. The use of (SEM) structural equation 
model has been observed to be a foremost procedure that has been used below different regression models and methods (Barron \& Kenny, 1986). It used to evaluate the structural relationship between exogenous and endogenous variables. It includes factor analysis and multivariate analysis. Moreover, the equation of regression targets at explaining each construct to assess the cause and effect relationship while all of the factors in the causal model could demonstrate their cause and effect at exact time. Likewise, the idea of using this model ensures to apply technique of bootstrapping which has been viewed as reasonable for both small and large sample size and does not require any kind of indirect effect (Hayes, 2013). In order to check the all direct and indirect effects, a technique has been implemented which is known as bootstrapping (Shrout \& Bolger, 2002).

\subsection{Measurement of Outer Model}

The goal of measure of fit in the measurement model is to study about the reliability and validity of the instrument and to check its reliability and validity we perform test of convergent validity and discriminant validity in software naming Smart PLS.

\subsubsection{Composite Reliablity}

Reliability implies stability of questionnaire outcomes. For the similar target population, at whatever point the questioner reutilize the questionnaire it will give similar outcome. It demonstrates inside consistency \& repeatability of the survey is high. The primary measure for unwavering quality is to maintain a strategic distance from unfairness in research. In this manner, it tends to be improved by testing the pursuit procedure and investigation, as is done utilizing diverse research and examination techniques or different researchers. This also incorporates the dependability and legitimacy of the exploration.

Reliability of the measurement instruments was evaluated using composite reliability. All the values were above the normally used threshold value i.e. 0.70 . This is the accepted reliability value range. Estimation of reliability can be done by degree of constancy that lies amongst various variables (Hair , 2010). Below is the table of composite reliability.

Table 3.

\begin{tabular}{|l|c|}
\hline \multicolumn{1}{|c|}{ Variables } & Composite Reliability \\
\hline Success & 0.747 \\
\hline Centrality & 0.657 \\
\hline Happiness & 0.770 \\
\hline Gratitude & 0.816 \\
\hline Negative Affect & 0.798 \\
\hline Positive Affect & 0.873 \\
\hline Life Satisfaction & 0.864 \\
\hline
\end{tabular}

Note. All the values of Composite Reliability fall in acceptable region except centrality. 
5.4 Factors Loading Significant

Table 4. (See Table 2. For full questions)

\begin{tabular}{|c|c|c|c|c|}
\hline $\begin{array}{c}\text { Questions } \\
\text { (Code) }\end{array}$ & Construct & $\begin{array}{c}\text { Item } \\
\text { Loading }\end{array}$ & T-value & P-value \\
\hline Q1 & Success & 0.681 & 7.045 & 0.000 \\
\hline Q2 & Success & 0.699 & 7.784 & 0.000 \\
\hline Q3 & Success & 0.486 & 3.725 & 0.000 \\
\hline Q4 & Success & 0.737 & 13.318 & 0.000 \\
\hline Q5 & Success & 0.418 & 2.784 & 0.006 \\
\hline Q6 & Centrality & 0.828 & 14.724 & 0.000 \\
\hline Q7 & Centrality & 0.850 & 15.442 & 0.000 \\
\hline Q8 & Centrality & 0.308 & 2.159 & 0.031 \\
\hline Q9 & Centrality & 0.175 & 1.190 & 0.235 \\
\hline Q10 & Centrality & 0.364 & 2.811 & 0.005 \\
\hline Q11 & Happiness & 0.701 & 11.657 & 0.000 \\
\hline Q12 & Happiness & 0.761 & 12.513 & 0.000 \\
\hline Q13 & Happiness & 0.681 & 7.978 & 0.000 \\
\hline Q14 & Happiness & 0.584 & 5.904 & 0.000 \\
\hline Q15 & Happiness & 0.414 & 3.523 & 0.000 \\
\hline Q16 & Gratitude & 0.822 & 27.689 & 0.000 \\
\hline Q17 & Gratitude & 0.794 & 21.070 & 0.000 \\
\hline Q18 & Gratitude & -0.025 & 0.227 & 0.820 \\
\hline Q19 & Gratitude & 0.830 & 35.713 & 0.000 \\
\hline Q20 & Gratitude & 0.817 & 27.546 & 0.000 \\
\hline Q21 & Gratitude & 0.476 & 5.292 & 0.000 \\
\hline Q22 & Positive Affect & 0.807 & 26.323 & 0.000 \\
\hline Q23 & Negative Affect & 0.698 & 3.749 & 0.000 \\
\hline Q24 & Positive Affect & 0.759 & 17.257 & 0.000 \\
\hline Q25 & Negative Affect & 0.551 & 3.173 & 0.002 \\
\hline Q26 & Positive Affect & 0.819 & 25.793 & 0.000 \\
\hline Q27 & Negative Affect & 0.796 & 4.281 & 0.000 \\
\hline Q28 & Positive Affect & 0.843 & 29.658 & 0.000 \\
\hline Q29 & Negative Affect & 0.748 & 4.186 & 0.000 \\
\hline Q30 & Negative Affect & 0.562 & 3.032 & 0.003 \\
\hline Q31 & Positive Affect & 0.702 & 13.931 & 0.000 \\
\hline Q32 & Negative Affect & 0.386 & 1.513 & 0.131 \\
\hline Q33 & Positive Affect & 0.403 & 4.997 & 0.000 \\
\hline Q34 & Life Satisfaction & 0.667 & 11.468 & 0.000 \\
\hline Q35 & Life Satisfaction & 0.851 & 36.954 & 0.000 \\
\hline Q36 & Life Satisfaction & 0.842 & 29.371 & 0.000 \\
\hline Q37 & Life Satisfaction & 0.791 & 25.439 & 0.000 \\
\hline Q38 & Life Satisfaction & 0.564 & 9.642 & 0.000 \\
\hline
\end{tabular}




\section{MlMacrothink}

International Journal of Management Innovation Systems

ISSN 1943-1384

Description of the above table:

Above is the mentioned table of (CFA) confirmatory factor analysis with the loadings. Construct with the loading of .5 are consider as strong loading variables whereas the constructs with the loading of below .5 are considered as less are better to be removed from the table.

\subsection{Convergent Validity}

Convergent validity is the level of agreement in at least two measures of a similar construct (Carmines and Zeller, 1979). Convergent validity was assessed by inspection of variance mined for each factor (Fornell and Larcker, 1981). Conferring to Fornell and Larcker (1981), if the, variance extracted value is greater than 0.5 then convergent validity is established and the result is drawn that the loadings are good but less than 0.5 are termed as less effective for the study.

Following table displays the result.

Table 5.

\begin{tabular}{|c|c|c|c|}
\hline Variables & $\begin{array}{c}\text { Cronbach's } \\
\text { Alpha }\end{array}$ & $\begin{array}{c}\text { Composite } \\
\text { Reliability }\end{array}$ & $\begin{array}{c}\text { Average Variance Extracted } \\
\text { (AVE) }\end{array}$ \\
\hline Success & 0.603 & 0.747 & 0.382 \\
\hline Centrality & 0.447 & 0.657 & 0.334 \\
\hline Happiness & 0.657 & 0.770 & 0.409 \\
\hline Gratitude & 0.703 & 0.816 & 0.482 \\
\hline Negative Affect & 0.719 & 0.798 & 0.408 \\
\hline Positive Affect & 0.821 & 0.873 & 0.544 \\
\hline Life Satisfaction & 0.803 & 0.864 & 0.565 \\
\hline
\end{tabular}

\subsection{Discriminant Validity}

Discriminate validity can be defined as any single construct when differs from other constructs in the model (Carmines \& Zeller, 1979). Discriminate validity results are satisfactory when the constructs are having value below 0.90. Discriminate validity is established if the elements which are in diagonal are significantly higher than those values in off-diagonal in the parallel rows and columns. Discriminant Validity tests are being conducted in order to see whether non-related ideas or measurements are in fact unrelated or not. An effective assessment of discriminant legitimacy demonstrates that a trial of an idea isn't exceptionally associated with different tests intended to quantify hypothetically various ideas. The table for Discriminant Validity is given below: 
Table 6.

\begin{tabular}{llllllll}
\hline & Centrality & Gratitude & Happiness & $\begin{array}{c}\text { Life } \\
\text { Satisfaction }\end{array}$ & $\begin{array}{c}\text { Negative } \\
\text { Affect }\end{array}$ & $\begin{array}{c}\text { Positive } \\
\text { Affect }\end{array}$ & Success \\
\hline Centrality & 0.578 & & & & & & \\
Gratitude & 0.563 & 0.694 & & & & & \\
Happiness & 0.468 & 0.469 & 0.640 & & & & \\
Life Satisfaction & 0.358 & 0.555 & 0.422 & 0.751 & & & \\
Negative Affect & 0.041 & -0.015 & 0.036 & 0.188 & 0.639 & & \\
Positive Affect & 0.354 & 0.346 & 0.344 & 0.576 & 0.288 & 0.737 & \\
Success & 0.504 & 0.408 & 0.510 & 0.335 & 0.122 & 0.246 & 0.618 \\
\hline
\end{tabular}

Note. Above table evidently shows that discriminant results are satisfactory as all values are below 0.90 .

\subsection{Model Fit Measures}

The fitness of the model in SEM-PLS is defined by various measures such as standardized root-mean-square residual (SRMR), and the exact model fits like d_ULS and d_G, Normed Fit Index (NFI), and $\chi^{2}$ (Chi-square). The model fit measures consisting the measured value of both saturated model as well as the estimated model is reported in above Table. The saturated model assesses the correlation between all constructs. The estimated model, on the other hand, takes model structure into account and is based on total effect scheme.

Table 7A. (For Model 1)

\begin{tabular}{ccc}
\hline Fit Summary & Saturated Model & Estimated Model \\
\hline SRMR & 0.095 & 0.100 \\
d_ULS & 6.722 & 7.371 \\
d_G & 1.402 & 1.426 \\
Chi-Square & $1,528.687$ & $1,546.106$ \\
NFI & 0.557 & 0.552 \\
\hline
\end{tabular}

Table 7B: (For Model 2)

\begin{tabular}{ccc}
\hline Fit Summary & Saturated Model & Estimated Model \\
SRMR & 0.095 & 0.105 \\
d_ULS & 6.702 & 8.103 \\
d_G & 1.405 & 1.497 \\
Chi-Square & $1,529.973$ & $1,583.338$ \\
NFI & 0.556 & 0.540 \\
\hline
\end{tabular}




\section{Macrothink}

\subsection{Hypothesis Testing}

In PLS-SEM, bootstrapping is one of the key strides, which gives the data of constancy of factor guesstimate. Sub-tests are drawn everywhere from the first example including substitution, in this process (Hair, Matthews, Matthews, \& Sarstedt, 2017). Bootstrapping provides the information of stability of coefficient estimate. In this process, a large number of sub-samples are drawn from the original sample with replacement (Hair et al., 2016). After running the bootstrap routine, SmartPLS shows the t-values for structural model estimates derived from the bootstrapping procedure. The results of path coefficients for all the hypothesis are shown in the following table. The $\mathrm{t}$-value greater than $1.96(\mathrm{p}<.005)$ shows that the relationship is significant at $95 \%$ confidence level $(\alpha=0.05)$. Paths showing whether the relationship between measured and latent variables are significant or not. The path diagram showed in figure 2 .

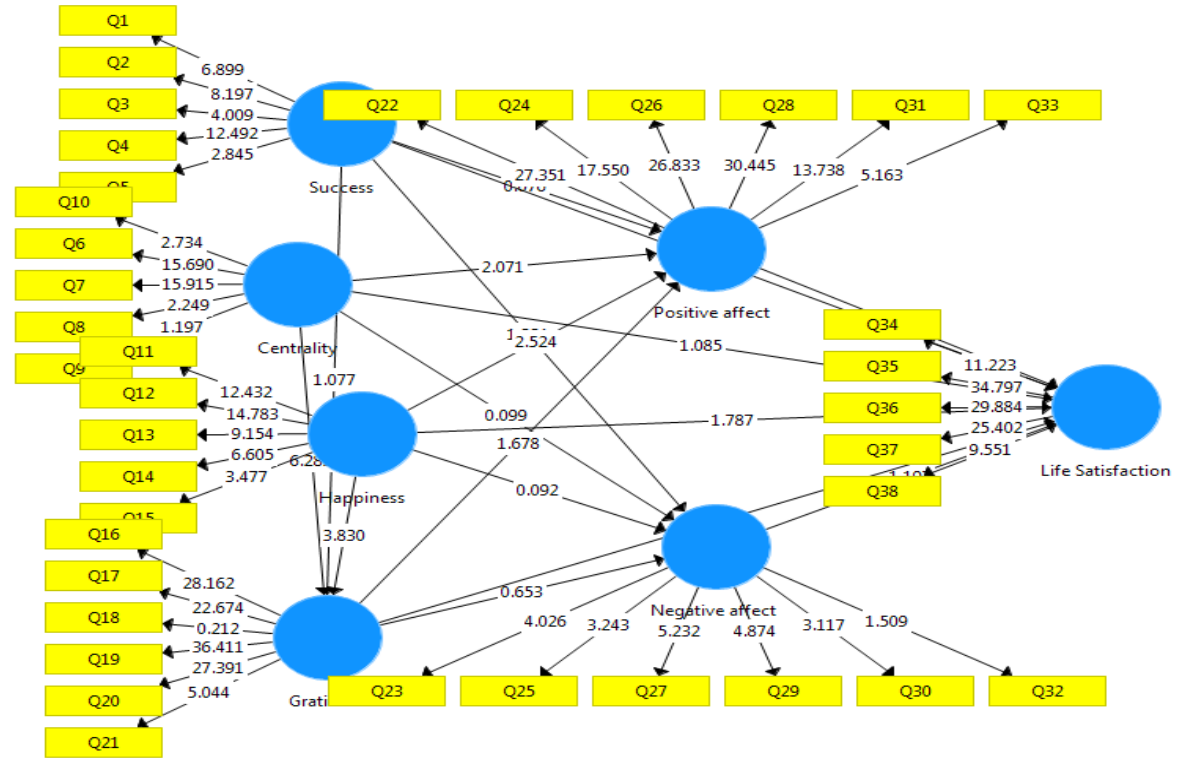

Model 1

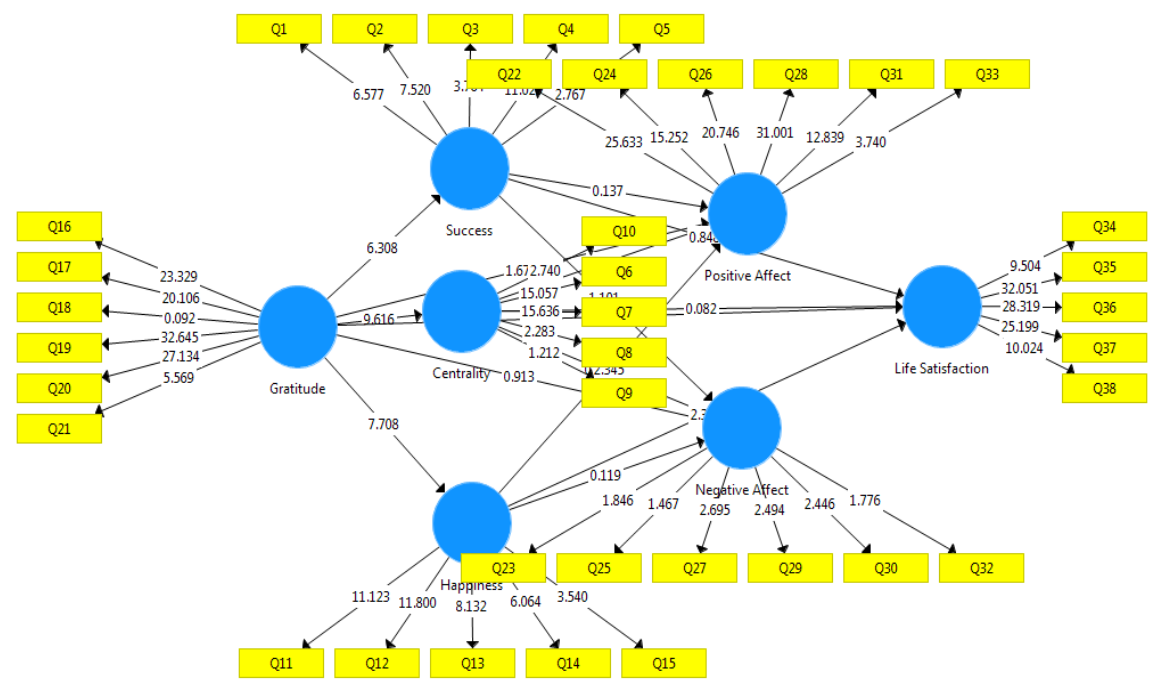

Model 2

Figure 2. 
Table 8A. (For Model 1)

\begin{tabular}{|c|c|c|c|c|}
\hline Hypothesis & $\begin{array}{l}\text { Standard } \\
\text { Deviation } \\
\text { (STDEV) }\end{array}$ & $\begin{array}{c}\text { T } \\
\text {-values }\end{array}$ & $\begin{array}{c}P \\
\text {-values }\end{array}$ & Decision \\
\hline $\begin{array}{l}\text { H1: Success has a significant negative impact on } \\
\text { gratitude. }\end{array}$ & 0.077 & 1.030 & 0.304 & $\begin{array}{c}\text { Not } \\
\text { Supported }\end{array}$ \\
\hline $\begin{array}{l}\text { H2: Success has a significant negative impact on } \\
\text { life satisfaction. }\end{array}$ & 0.070 & 0.791 & 0.430 & $\begin{array}{c}\text { Not } \\
\text { Supported }\end{array}$ \\
\hline H3: Success is associated with negative affect. & 0.119 & 1.294 & 0.196 & $\begin{array}{c}\text { Not } \\
\text { Supported }\end{array}$ \\
\hline $\begin{array}{l}\text { H4: Success has negative relationship with } \\
\text { positive affect. }\end{array}$ & 0.086 & 2.132 & 0.033 & Supp \\
\hline $\begin{array}{l}\text { H5: Centrality has a significant negative impact } \\
\text { on gratitude. }\end{array}$ & 0.069 & 0.016 & 0.000 & Supported \\
\hline $\begin{array}{l}\text { H6: Centrality has a significant negative impact } \\
\text { on life satisfaction. }\end{array}$ & 0.078 & 1.145 & 0.253 & $\begin{array}{c}\text { Not } \\
\text { Supported }\end{array}$ \\
\hline H7: Centrality is associated with negative affect. & 0.150 & 0.097 & 0.922 & $\begin{array}{c}\text { Not } \\
\text { Supported }\end{array}$ \\
\hline $\begin{array}{l}\text { H8: Centrality has negative relationship with } \\
\text { positive affect. }\end{array}$ & 0.098 & 1.868 & 0.062 & $\begin{array}{c}\text { Not } \\
\text { Supported }\end{array}$ \\
\hline $\begin{array}{l}\text { H9: Seeking happiness with material possession } \\
\text { has a significant negative impact on gratitude. }\end{array}$ & 0.062 & 3.803 & 0.000 & Supported \\
\hline $\begin{array}{l}\text { H10: Seeking happiness with material possession } \\
\text { has a significant negative impact on life } \\
\text { satisfaction. }\end{array}$ & 0.063 & 1.764 & 0.078 & $\begin{array}{c}\text { Not } \\
\text { Supported }\end{array}$ \\
\hline $\begin{array}{l}\text { H11: Seeking happiness with material possession } \\
\text { is associated with negative affect. }\end{array}$ & 0.131 & 0.089 & 0.929 & $\begin{array}{c}\text { Not } \\
\text { Supported }\end{array}$ \\
\hline $\begin{array}{l}\text { H12: Seeking happiness with material possession } \\
\text { has negative relationship with positive affect. }\end{array}$ & 0.075 & 2.499 & 0.013 & Supported \\
\hline $\begin{array}{l}\text { H13: Negative affect would mediate the effect of } \\
\text { materialism (i.e. Success, Centrality and } \\
\text { Happiness) on life satisfaction. }\end{array}$ & 0.0799 & 089 & 0.276 & $\begin{array}{c}\text { Not } \\
\text { Supported }\end{array}$ \\
\hline $\begin{array}{l}\text { H14: Positive Affect would mediate the effect of } \\
\text { gratitude on life satisfaction. }\end{array}$ & 0.068 & 5.881 & 0.000 & Supported \\
\hline $\begin{array}{l}\text { H15: Gratitude is significantly associated with } \\
\text { positive affect. }\end{array}$ & 0.095 & 1.656 & 0.098 & $\begin{array}{c}\text { Not } \\
\text { Supported }\end{array}$ \\
\hline $\begin{array}{l}\text { H16: Gratitude has a negative relationship with } \\
\text { negative affect. }\end{array}$ & 0.130 & 0.622 & 0.534 & $\begin{array}{c}\text { Not } \\
\text { Supported }\end{array}$ \\
\hline $\begin{array}{l}\text { H17: Gratitude has a significant positive } \\
\text { relationship with life satisfaction. }\end{array}$ & 0.063 & 6.239 & 0.000 & Supported \\
\hline
\end{tabular}




\section{MInstitute ${ }^{\text {Macrothink }}$}

International Journal of Management Innovation Systems

ISSN 1943-1384

Description for the above table.

In this model, for success out of for hypothesis only one is supporting our result i.e. hypothesis 4 (Success has negative relationship with positive affect) although hypothesis 1,2 \& 3 is not supported because t-value is less than 1.96 so, it is proved that the relationship is not significant. Further, in centrality there is also only one hypothesis supporting our result i.e. hypothesis 5 (Centrality has a significant negative impact on gratitude) as $p<0.005$ rest are not supporting. Seeking happiness through material possessions there are two hypothesis which is supported our result i.e. hypothesis 9 (Seeking happiness with material possession has a significant negative impact on gratitude) \& hypothesis 12 (Seeking happiness with material possession has negative relationship with positive affect) as $t>1.96$ shows the significant relationship others are not supported. For mediatory role results are not supported hypothesis 13 (Negative affect would mediate the effect of materialism (i.e. Success, Centrality and Happiness) on life satisfaction) and supported hypothesis 14 (Positive Affect would mediate the effect of gratitude on life satisfaction) as $p<0.005 \& t>1.96$. For gratitude hypothesis 17 is supported by our result i.e. (Gratitude has a significant positive relationship with life satisfaction) as $\mathrm{p}<0.005 \& \mathrm{t}>1.96$ while hypothesis $15 \& 16$ are not supported because $p>0.005 \& \mathrm{t}<1.96$ for both.

Table 8B. (For Model 2)

\begin{tabular}{|l|c|c|c|c|}
\hline \multicolumn{1}{|c|}{ Hypothesis } & $\begin{array}{c}\text { Standard } \\
\text { Deviation } \\
\text { (STDEV) }\end{array}$ & $\begin{array}{c}\text { T } \\
\text {-values }\end{array}$ & P -values & Decision \\
\hline $\begin{array}{l}\text { H1: Gratitude has an inverse relationship with } \\
\text { success. }\end{array}$ & 0.061 & 6.884 & 0.000 & Supported \\
\hline $\begin{array}{l}\text { H2: Gratitude has an inverse relationship with } \\
\text { Centrality. }\end{array}$ & 0.056 & 10.116 & 0.000 & Supported \\
\hline $\begin{array}{l}\text { H3: Gratitude has an inverse relationship with } \\
\text { happiness. }\end{array}$ & 0.058 & 1.185 & 0.000 & Supported \\
\hline $\begin{array}{l}\text { H4: Gratitude is associated with positive } \\
\text { affect. }\end{array}$ & 0.094 & 1.666 & 0.096 & $\begin{array}{c}\text { Not } \\
\text { Supported }\end{array}$ \\
\hline $\begin{array}{l}\text { H5: Gratitude has negative relationship with } \\
\text { negative affect. }\end{array}$ & 0.127 & 0.691 & 0.490 & $\begin{array}{c}\text { Not } \\
\text { Supported }\end{array}$ \\
\hline $\begin{array}{l}\text { H6: Gratitude has a significant positive } \\
\text { impact on life satisfaction. }\end{array}$ & 0.065 & 6.106 & 0.000 & Supported \\
\hline $\begin{array}{l}\text { H7: Success has a significant negative impact } \\
\text { on life satisfaction. }\end{array}$ & 0.073 & 0.683 & 0.495 & $\begin{array}{c}\text { Not } \\
\text { Supported }\end{array}$ \\
\hline $\begin{array}{l}\text { H8: Success is associated with negative } \\
\text { affect. }\end{array}$ & 0.111 & 1.379 & 0.168 & $\begin{array}{c}\text { Not } \\
\text { Supported }\end{array}$ \\
\hline $\begin{array}{l}\text { H9: Success has negative relationship with } \\
\text { positive affect. }\end{array}$ & 0.085 & 0.108 & 0.914 & $\begin{array}{c}\text { Not } \\
\text { Supported }\end{array}$ \\
\hline
\end{tabular}




\begin{tabular}{|c|c|c|c|c|}
\hline $\begin{array}{l}\text { H10: Centrality has a significant negative } \\
\text { impact on life satisfaction. }\end{array}$ & 0.078 & 1.141 & 0.255 & $\begin{array}{c}\text { Not } \\
\text { Supported }\end{array}$ \\
\hline $\begin{array}{l}\text { H11: Centrality is associated with negative } \\
\text { affect. }\end{array}$ & 0.096 & 0.130 & 0.897 & $\begin{array}{c}\text { Not } \\
\text { Supported }\end{array}$ \\
\hline $\begin{array}{l}\text { H12: Centrality has negative relationship with } \\
\text { positive affect. }\end{array}$ & 0.096 & 1.927 & 0.055 & $\begin{array}{c}\text { Not } \\
\text { Supported }\end{array}$ \\
\hline $\begin{array}{l}\text { H13: Seeking happiness with material } \\
\text { possession has a significant negative impact } \\
\text { on life satisfaction. }\end{array}$ & 0.067 & 1.683 & 0.102 & $\begin{array}{c}\text { Not } \\
\text { Supported }\end{array}$ \\
\hline $\begin{array}{l}\text { H14: Seeking happiness with material } \\
\text { possession is associated with negative affect. }\end{array}$ & 0.125 & 0.091 & 0.927 & $\begin{array}{c}\text { Not } \\
\text { Supported }\end{array}$ \\
\hline $\begin{array}{l}\text { H15: Seeking happiness with material } \\
\text { possession has negative relationship with } \\
\text { positive affect. }\end{array}$ & 0.076 & 1.104 & 2.466 & Supported \\
\hline $\begin{array}{l}\text { H16: Negative affect would mediate the } \\
\text { effect of materialism (i.e. Success, Centrality } \\
\text { and Happiness) on life satisfaction. }\end{array}$ & 0.068 & 1.104 & 0.270 & $\begin{array}{c}\text { Not } \\
\text { Supported }\end{array}$ \\
\hline $\begin{array}{l}\text { H117: Positive Affect would mediate the } \\
\text { effect of gratitude on life satisfaction. }\end{array}$ & 0.0 & 6.088 & 0.000 & Supported \\
\hline
\end{tabular}

Description for the above table.

In Model 2, hypothesis 1,2,3 \& 6 are supported belongs to variable gratitude as $p<0.005$ while hypothesis $4 \& 5$ are not supported i.e. (Gratitude is associated with positive affect) \& (Gratitude has negative relationship with negative affect). For success hypothesis 7, 8 \& 9 all hypothesis is not supported as t-values for these hypotheses is less than 1.96. for centrality, hypothesis $10,11 \& 12$ also not supported as $t<1.96$. Hypothesis $13,14 \& 15$ seeking happiness through material possession only hypothesis 14 is supported i.e. (Seeking happiness with material possession has negative relationship with positive affect). Although for mediatory role hypothesis 16 is not supported (Negative affect would mediate the effect of materialism (i.e. Success, Centrality and Happiness) on life satisfaction) while hypothesis 17 is supported (Positive Affect would mediate the effect of gratitude on life satisfaction) as $\mathrm{t}>1.96$ and $\mathrm{p}<0.005$.

\section{Discussion}

These data help to explain that numerous studies demonstrate materialism is related to decreased in life satisfaction in one's life satisfaction but when we apply this fact on employee's life in one of the developing countries i.e. Pakistan by taking materialism as three components i.e. success, centrality and happiness the result did not support the hypothesis. As further predicted, materialism i.e. success, centrality and happiness are associated with negative affect as previous researches but the result suggested no relationship.

Additionally, employee's with high gratitude have higher satisfaction with their life and relate 
with positive affect as consistent with previous research. It is proved that Pakistani employees are not seeking happiness through material things they are happy and satisfied with their life because higher level of gratitude are found in their life.

However, data collected through Pakistani employees suggests that centrality, or making acquisition of material possessions a central focus of one's life has a significant negative impact on gratitude but success, or viewing possessions as a maker of success is not supported this hypothesis there is no negative relationship between success and gratitude. Seeking happiness through material purchase also oppose the negative relationship of materialism and gratitude. As different researches explain that higher level of materialism decrease the effect of gratitude in one's life but in this data, there is no such effect found in employee's life in Pakistan. As result showed, they already have higher amount of gratitude in their life. They are somehow satisfied with their life's current situation with the things they have in their life that is why the result is not consistent with previous research.

Regarding the predicted mediatory role of negative affect and positive affect, findings revealed that, taking feeling experiences as mediatory role there is no direct and significant mediatory effect found between negative affect and materialism on employee's life as previous research argued that negative affect would mediate the effect materialism in one's life but in Pakistani employee's life there is no such effect found according to result. Suggesting that negative affect might be serves to partially (as opposed to fully) mediate the effect of materialism on employee's life satisfaction. Although, result supported that positive affect would mediate the effect of gratitude on life satisfaction of employee's as consistent with previous researches. suggests that, gratitude and positive affect lessened the negative effects of materialism in employee's life.

Further, theories of previous researches argued that there is an inverse relationship between materialism and gratitude in individual's life in current study by taking materialism as three components i.e. success, centrality and happiness it is analyzed that in employee's life there is also an inverse relationship between materialism and gratitude and result supported this hypothesis. If materialism increases gratitude decreases in employee's life and ultimately, they will lose their positivity and life satisfaction and vice versa.

Further research might explore the mechanism underlying the relationship between these variables' gratitude, materialism and life satisfaction. For example, how this relationship would be more beneficial by focus on the self and possible reasons why there is an inverse relationship between materialism and gratitude. Another possible mechanism might be differences in focus of attention between materialism and gratitude. Materialistic goals may be related to a focus on possessions that one wants but currently lacks, whereas gratitude might be related to an attitude of savoring what one already has (McCullough, Emmons, \& Tsang, 2002). By changing people's frame of reference, the results might be completely change. Further research may explore more facts about these variables by taking data from different population. More research may explore that how industry would take benefit of these type of employee's and how they provide competitive edge to the company. Employees are assets for any company which cannot be imitate by other if they will know how much 


\section{Mll Macrothink}

International Journal of Management Innovation Systems

ISSN 1943-1384

2019, Vol. 4, No. 1

beneficial these employees are for them and how they will take advantage of these type of employees they will make their retention plans and policies stronger to retain their assets which will provide them advantage in future.

\section{Conclusion}

It is concluded that employees who are happy with their current life situation and the things they have are satisfied with their life more than those who are seeking happiness through material purchases and spoil their life satisfaction in search for more. However, higher level of gratitude decreases the negative effect of materialism from employee's life and increases the level of life satisfaction. Figure 1 shows diagrams of two model which is a modified form of J.A. Roberts. In first model success, centrality and happiness are independent variables and all others are dependent while in second model gratitude is independent variable taking all others as dependent variables.

Then established hypothesis through the study of various researches 17 hypothesis for each model has been developed total 34 hypothesis some of them are similar for both models. Data were collected through employees of different sectors in Pakistan through online and manually both. Table 1 presented the descriptive statistics of demographic profile that shows $63 \%$ male and $37 \%$ female were participated in this survey, majority earns monthly income in range 20,000-40,000 PKR, mostly participants were graduate and masters, majority belongs to age group 25-35 years i.e. 111 out of 209 participants from different professions and different sectors of Pakistan. Scales for measurement was adopted from different research scholars.

Table 2 indicates the mean, standard deviation and standard error of all core indicators. Table 3A \& 3B presented the composite reliability for both model in which all values are fall in acceptable region i.e. above 0.70 except centrality. Centrality has composite reliability of $\alpha=0.657$ and $\alpha=0.659$ for model 2 which is below 0.70 . Table $4 \mathrm{~A}$ and $4 \mathrm{~B}$ presented the values of factors loading significant for both models mostly variables construct with the loadings of above 0.5 which is satisfactory.

Table 5A and 5B presented the results of convergent validity for all variables of both models which is found satisfactory as all values are above 0.5 . For success; $\alpha=0.603$, centrality; $\alpha=0.447$, happiness; $\alpha=0.657$, gratitude; $\alpha=0.703$, positive affect; $\alpha=0.82$, negative affect; $\alpha=0.719$ and life satisfaction; $\alpha=0.803$ except centrality all value's validity are satisfactory. Table 6A and 6B indicates the discriminant validity for both models and results evidently shows that validity of all variables is satisfactory as all values are below 0.90 . Table 7A and $7 \mathrm{~b}$ shows the exact model fit measures d_ULS, d_G, chi-square and NFI. Table 8A and 8B shows the results of hypothesis testing and results lead to conclude that there is a wide difference when we measure these scales through individual's life and though employee's life because mostly result not supported our hypothesis. As I mentioned earlier there is no previous research found with the relationship of these variables either in developing countries or developed countries so, this research is also beneficial for further studies on employee's life satisfaction. The reason behind the opposite result also discussed in this paper. Through this research employee's and organization will came to know the fact that in Pakistan 
employees are not seeking happiness through material things they are happy with their current situation. If they will be appreciated and rewarded for their efforts and work, they will definitely work for the organization effectively and efficiently.

\section{Acknowledgements}

First and foremost, praises and thanks to almighty "Allah" who showers His blessings on me. Then I would like to express my special thanks to my supervisor Dr. Danish Siddiqui for giving me the opportunity to work under his guidance and provide invaluable advice and expertise throughout my work.

Nobody is more important in pursuit of this research article other than my family and friends. I am very grateful to all of them and their love, prayers and continuing support.

Finally, I offer my respects and endowments to all those who supported and promoted me in any regard aimed the fulfillment of this research.

\section{References}

Ashikali, E. M., \& Dittmar, H. (2011). The effect of priming materialism on women's responses to thin-ideal media. British Journal of Social Psychology, 1-20. https://doi.org/10.1111/j.2044-8309.2011.02020.x

Belk, R. W. (1985). Materialism: Trait Aspects of Living in the material world. The journal of consumer research, 265-280. https://doi.org/10.1086/208515

Bukharin, N. (1993). Marx's Teaching and its Historical Importance.

Chaplin, L. N., \& John, D. R. (2007). Growing up in a Material World: Age Differences in Materialism in Children and Adolescents. Journal of Consumer Research. https://doi.org/10.1086/518546

Christopher, A., N., Kuo, Abraham, K, N., Noel, ... H., E. (2004). Materialism and Affective well-being: The role of social support. Personality and individual differences, 37, 463-470. https://doi.org/10.1016/j.paid.2003.09.015

Cooyoumdjian, A., \& Petrocchi, N. (2016). The impact of gratitude on depression and anxiety: the mediating role of criticizing, attacking, and reassuring the self. Self and Identity, 191-205. https://doi.org/10.1080/15298868.2015.1095794

Deckop, J. R., Jurkiewicz, C. L., \& Giacalone, R. A. (2010). Effects of materialism on work-related personal well-being. Human Relations, 63(7), 1007-1030. https://doi.org/10.1177/0018726709353953

Diener, E., Emmons, R., Larsen, R., \& Griffin, S. (1985). The Satisfaction with life scale. Journal of pesonality assessment, 49, 71-75. https://doi.org/10.1207/s15327752jpa4901_13

Diener, E., Sapyta, J. J., \& Suh, E. M. (1998). Subjective well-being is essential to well-being Psychological Inquiry, 9, 33-37. https://doi.org/10.1207/s15327965pli0901_3 


\section{$\triangle$ Macrothink}

International Journal of Management Innovation Systems

ISSN 1943-1384

2019, Vol. 4, No. 1

Diener, E., Wirtz, D., Biswas-Diener, R., Tov, W., Kim-Prieto, C., Choi, D., \& Oishi, S. (2009). New measure of wellbeing; Assessing well-being: The collected works of Ed Diener. In A. C. Michalos (Ed.), (pp. 247-266). New York: NY: Springer. https://doi.org/10.1007/978-90-481-2354-4_12.

Disabato, D. J., Kashdan, T. B., Short, J. L., \& Jarden, A. (2017). What predicts positive life events that influence the course of depression? A longitudinal examination of gratitude and meaning in life. Cognitive Therapy and Research , 444-458.

Dittmar, Helga, Bond, Rod, Hurst, Megan, ... Tim. (2014). The relationship between materialism and personal well-being: A meta-analysis. Journal of Personality and Social Psychology, 107(5), 879-924. https://doi.org/10.1037/a0037409

Droge, c., R.D., \& Mackoy. (1995). The consumption culture versus environmentalism: Bridging value systems with environmental marketing. In P. Schildereller \& P. Kaufman (Eds.), Marketing and Public Policy Conference (pp. 227-232). (Atlanta, GA):

Dyck, B., \& Schroeder, D. (2005). Management, theology and moral points of view: Towards an alternative to the conventional materialist-individualist ideal-type of management. Journal of Management Studies, 42(4), 705-735. https://doi.org/10.1111/j.1467-6486.2005.00516.x

Emmons, R., \& McCulough, M. (2003). Counting blessings versus burdens: an experimental investigation of gratitude and subjective well-being in daily life. Journal of Social Psychology, 84(2), 377-389.

Erdogan , B., Bauer, T. N., Truxillo, D. M., \& Mansfield, L. R. (2011). Whistle While You Work: A Review of the Life Satisfaction Literature. Journal of Management https://doi.org/10.1177/0149206311429379

Froh, J. J., Emmons, R. A., Card, N. A., Bono, G., \& Wilson, J. A. (2011). Gratitude and the Reduced Costs of Materialism. Journal of happiniess studies, 289-302.

Gagne, M., \& Deci, E. (2005). Self-determination theory and work motivation. Journal of Organizational Behavior 26(4):, 331-362. https://doi.org/10.1002/job.322

Grant, A. M., \& Gino, F. (2001). A little thanks goes a long way: Explaining why gratitude expressions motivate prosocial behavior. Journal of Personality and Social Psychology.

Hair, J. F., Matthews, L. M., Matthews, R. M., \& Sarstedt, M. (2017). PLS-SEM or CB-SEM: updated guidelines on which method to use. Int. J. Multivariate Data Analysis, 107-123. Retrieved from https://www.google.com/url?sa=t\&rct=j\&q=\&esrc=s\&source=web\&cd=1\&cad=rja\&uact=8 \&ved=2ahUKEwj8mJ316LTiAhWBxIsKHbO2ApsQFjAAegQIBxAC\&url=https\%3A\%2F\% 2Fwww.researchgate.net\%2Fprofile\%2FThien_Sang_Lim\%2Fpost\%2FWhat_papers_or_ma nuals_do_you_recommend_the_most_to

Inglehart, R. (1990). Culture Shift in Advanced Industrial Society. Princeton,: NJ: Princeton University Press. https://doi.org/10.2307/2076175 


\section{MInstitute Macrothink $^{\text {Int }}$}

International Journal of Management Innovation Systems ISSN 1943-1384

Kashdan, T. B., \& Breen, W. E. (2007). Materialism and Diminished Well-Being: Experiential Avoidance as a Mediating Mechanism. Journal of Social and Clinical Psychology, 521-539. https://doi.org/10.1521/jscp.2007.26.5.521

Kasser, T. (2002). The high price of meterialism. Cambridge, MA: MIT Press.

Kasser, T., Vansteenkiste, M., \& Deckop, J. (2006). The ethical problems of a materialistic value The ethical problems of a materialistic value. In J. R. Deckop (Ed.), Human Resource Management Ethics (pp. 277-300). Greenwich: Information Age Publishers.

Lambert, N. M., Fincham, F. D., Stillman, T. F., \& Dean, L. R. (2009). More gratitude, less materialism:The mediating role of life satisfaction. The Journal of Positive Psychology, 32-42. https://doi.org/10.1080/17439760802216311

Lin, \& Che, C. (2015). Impact of Gratitude on Resource Development and Emotional Well-Being. Social Behavior and Personality: An international journal, 493-504. https://doi.org/10.2224/sbp.2015.43.3.493

Lyubomirsky, S., Sheldon, K. M., \& Schkade, D. (2007). Pursuing happiness: The architecture of sustainable change. Review of General Psychology. https://doi.org/10.1037/1089-2680.9.2.111.

McCullough, M., Emmons, R., \& Tsang, J. (2002). The grateful disposition: A conceptual and empirical topography. Journal of Personality and Social Psychology, 82, 112-127. https://doi.org/10.1037/0022-3514.82.1.112

McCullough, M. E., Tsang, J., \& Emmons, R. (2004). Gratitude in intermediate affective terrain: Links of grateful moods to individual differences. Journal of Personality and Social Psychology, 86, 295-309.

McCulough, M., Kilpatrick, S., Emmons, R., \& Larson, D. (2001). Is gratitude a moral affect? Psychological Bulletin, 127, 249-266.

Muceldili, B., Erdil, O., Akgun, A. E., \& Keskin, H. (2015). Collective Gratitude: Organizational Scholorship Perspective. International Business Research, 92-102. https://doi.org/10.5539/ibr.v8n8p92

Oliver, M. J. (1999). Capitalism, disability and ideology: a materialist critique of the normalization principle. Internet Publication URL, (16), 1-16.

Pieters, R. (2013). Bidirectional dinamics of materialism and loneliness: Not just a vicious cycle. Journal of Consumer Research, 40(4), 615-631. https://doi.org/10.1086/671564

Polak, E. L., \& McCullough, M. E. (2006). Is gratitude an alternative to materialism? Journal of Happiness Studies, 7(3), 343.

Promislo, M. D., Deckop, J. R., Giacalone, R. A., \& Jurkiewicz, C. L. (2011). Valuing money more than people: The effects of materialism on work-family conflict. Journal of Occupational and $\quad$ Organizational 935-953. https://doi.org/10.1348/096317909X480167 


\section{Macrothink}

International Journal of Management Innovation Systems

ISSN 1943-1384

Proyer, R. T., Ruch, W., \& Buschor, C. (2013). Testing Strengths-Based Interventions: A Preliminary Study on the Effectiveness of a Program Targeting Curiosity, Gratitude, Hope, Humor, and Zest for Enhancing Life Satisfaction. Journal Of Happiness Studies, 275-292.

Rakrachakarn , V., Moschis , G. p., Ong, F. S., \& Shannon, R. (2015). Materialism and Life Satisfaction: The role of religion. Journal of Religion and Health, 54(2), 413-426.

Richins, M. L., \& Dawson, S. (1992). A Consumer Values Orientation for Materialism and Its Measurement: Scale Development and Validation. Journal of Consumer Research, 303-316. https://doi.org/10.1086/209304

Roberts, J. A., Tsang, J. A., \& Manolis, C. (2015). Looking for happiness in all the wrong places: The moderating role of gratitude and affect in the materialism-life satisfaction relationship. The Journal of Positive Psychology, 1-10. http://dx.doi.org/10.1080/17439760.2015.1004553

Sansone, L. A., \& Sansone, R. A. (2010). Gratitude and Well Being: The Benefits of Appreciation. Psychiatry (Edgmont) 7(11), 18-20. https://doi.org/10.1016/j.cpr.2010.03.005

Sirgy, J. (1998). Materialism and quality of life Social Indicators Research, 43. 227-260.

Swyngedoun, E. (2000). The Marxian Alternative: Historical=geographical materialism and the political ecinomy of capitalism. In J. A. Angrew (Ed.), A companian to economic geography (pp. 41-59). Los Angeles: A companian to the city Gary Bridge and Sophie Watson.

Tsang, J. (2007). Gratitude for small and large favors . The journal positive psychology, 157-167. https://doi.org/10.1080/17439760701229019

Tsang, J. A., Carpenter, T. P., Roberts, J. A., Frisch, M. B., \& Carlisle, R. D. ( 2014). Why are materialist less happy? The role of gratitude and need satisfaction in the relationship between materialism and life satisfaction. Personality and Individual Differences, 62-66. https://doi.org/10.1016/j.paid.2014.02.009

Wang, G., Liu, L., Tan, X., \& Zheng, W. (2017). The moderating effect of dispositional mindfulness on the relationship between materialism and mental health. Personality and Individual Differences, 131-136. https://doi.org/10.1016/j.paid.2016.11.041

Watkins, P. (2014). Gratitude and the good life. https://doi.org/10.1007/978-94-007-7253-3

Watkins, P., Woodward, K., Stone, T., \& Kolts, R. (2003). Gratitude and happiness: Development of a measure of gratitude, and relationships with subjective wellbeing. Social Behavior and Personality: An International Journal, 31, 431-451. https://doi.org/10.2224/sbp.2003.31.5.431 


\section{IIMacrothink

\section{Appendix}

Appendix 1. Survey Questionnaire:

1. Gender:

$$
\begin{aligned}
& \circ \text { Male } \\
& \circ \text { Female }
\end{aligned}
$$

2. Age:

$$
\begin{aligned}
& \circ 20-25 \\
& \circ 25-35 \\
& \circ 35-45 \\
& \circ 45 \& \text { above }
\end{aligned}
$$

3. Marital Status:

○ Single

- Married

4. Income Level (In PKR):

$$
\begin{aligned}
& \circ 20 \mathrm{k}-40 \mathrm{k} \\
& \circ 40 \mathrm{k}-60 \mathrm{k} \\
& \circ 60 \mathrm{k}-80 \mathrm{k} \\
& \circ 80 \mathrm{k}-100 \mathrm{k} \\
& \circ 100 \mathrm{k} \& \text { above }
\end{aligned}
$$

5. Level of Education:

o Intermediate

- Graduation

o Masters

$\circ$ M.Phil.

$\circ \mathrm{PhD}$

6. Your Profession:
o Doctor
$\circ$ Engineer
o Self-employed
$\circ$ Entrepreneur
o Employee
o Other (Please Specify):

Success:

7. I admire people who own expensive homes, cars, and clothes.

8. Some of the most important achievements in life in-clued acquiring material possessions.

9. I don't place much emphasis on the amount of material objects people own as a sign of success.

10. The things I own say a lot about how well I'm doing in life.

Centrality:

11. I usually buy only the things I need.

12. I try to keep myself simple, as far as possessions are concerned. 


\section{Macrothink

13. The things I owned aren't all the important to me.

14. I enjoy spending money on things that aren't practical to me.

15. Buying things gives me a lot of pleasure.

Happiness:

16. I have all the things I really need to enjoy life.

17. My life would be better if I owned certain things I don't have.

18. I'd be happier if I could afford to buy more things.

19. It sometimes bothers me quite a bit that I can't afford to buy all the things I'd like.

20. I wouldn't be happier if I owned nicer things.

Gratitude:

21. I have so much in life to be thankful for.

22. If I had to list everything that I felt grateful for, it would be a very long list.

23. When I look at the world, I don't see much to be grateful for.

24. I am grateful to a wide variety of people.

25. As I get older, I find myself more able to appreciate the people events, and situations that have been part of my life history.

26. Long amounts of time can go by before I feel grateful to something or someone.

Positive and Negative Affect (Feeling Experiences):

27. Positive

28. Negative

29. Good

30. Bad

31. Pleasant

32. Unpleasant

33. Happy

34. Sad

35. Afraid

36. Joyful

37. Angry

38. Contended

Life Satisfaction:

39. In most ways my life is close to my ideal.

40. The conditions of life are excellent.

41. I am satisfied with my life.

42. So far, I have gotten the important things I want in my life.

43. If I could live my life over, I would change almost nothing. 
Appendix 2. Charts for demographic profile

Gender

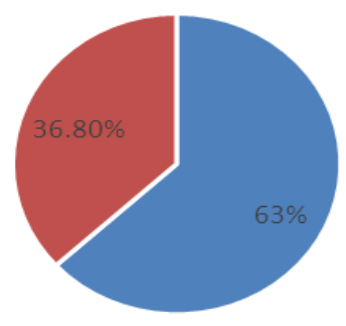

- Male - Female

Marital Status

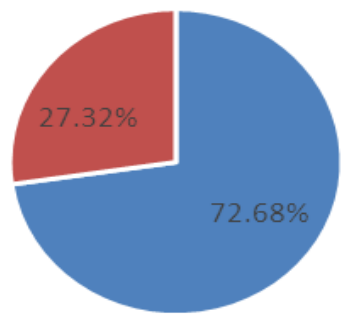

- Single - Married
Age (In years)

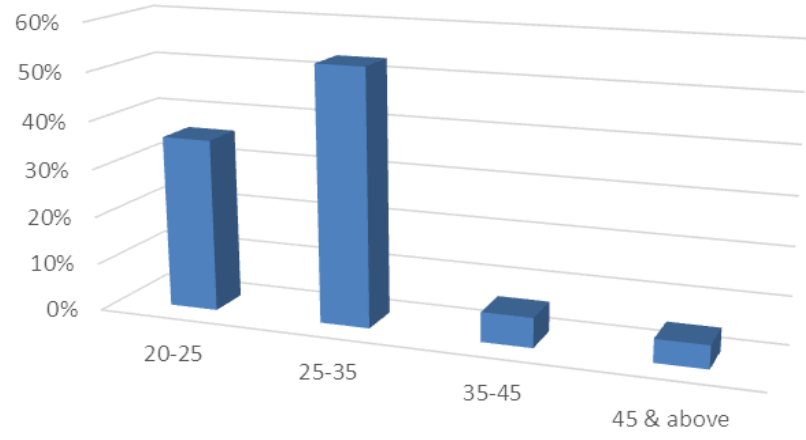

\section{Profession}

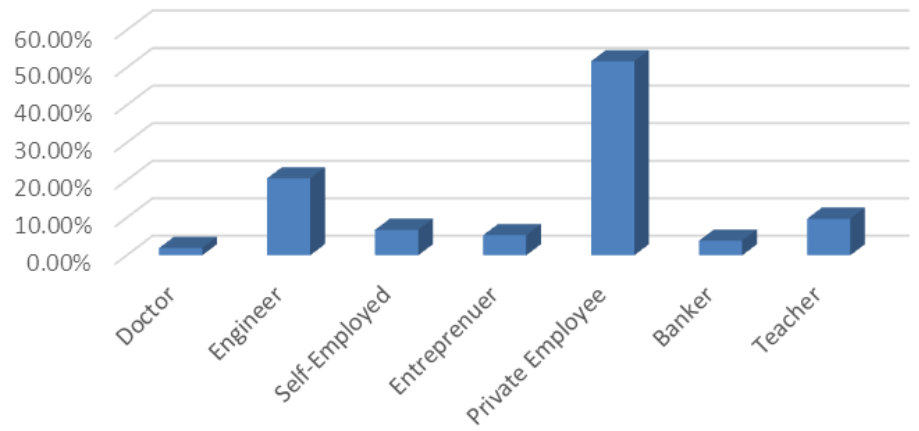

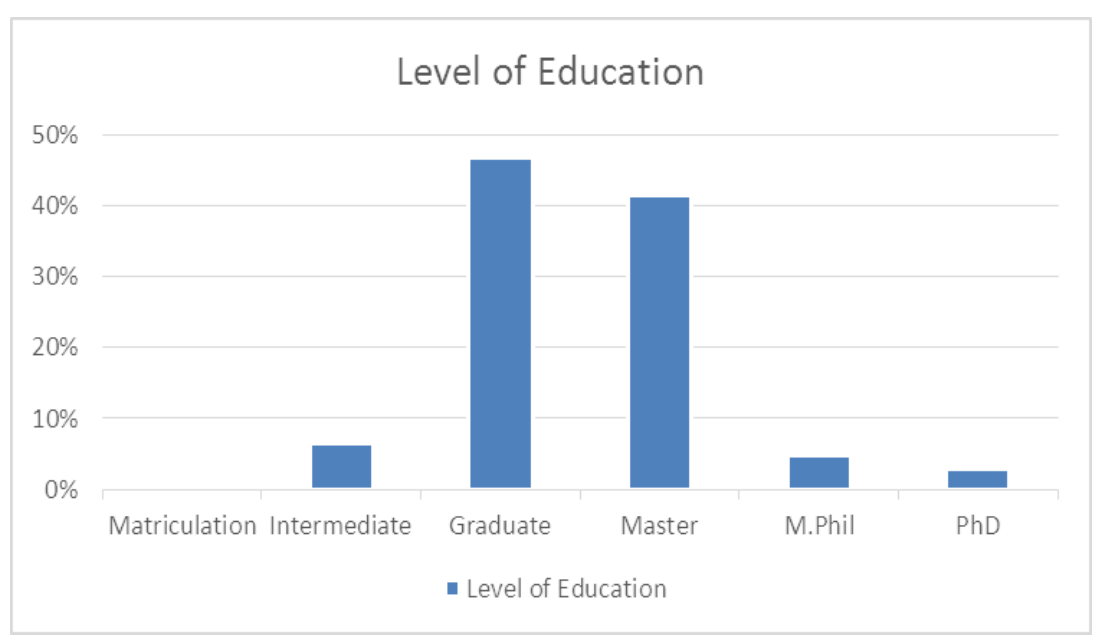




\section{Macrothink \\ International Journal of Management Innovation Systems \\ ISSN 1943-1384 \\ 2019, Vol. 4, No. 1}

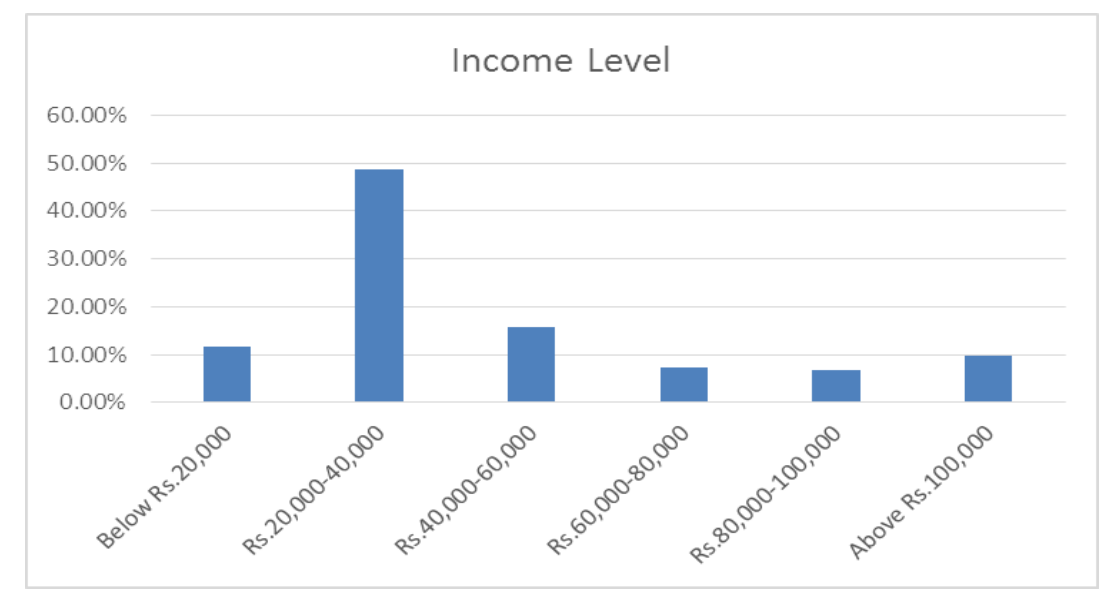

\section{Copyright Disclaimer}

Copyright for this article is retained by the author(s), with first publication rights granted to the journal.

This is an open-access article distributed under the terms and conditions of the Creative Commons Attribution license (http://creativecommons.org/licenses/by/3.0/). 